\title{
Toxoplasmosis seroepidemiology in pregnant women in a city in the Northwest region of the Paraná State, Brazil
}

\author{
[Soroepidemiologia da toxoplasmose em gestantes em uma cidade na região noroeste \\ do estado do Paraná, Brasil]
}

\section{"Artigo Científico/Scientific Article"}

\author{
Isabel Cristina da Silva Caetano ${ }^{1 *}$, Graziela Vendrame Rodrigues ${ }^{1}$, Daniela Dib Gonçalves ${ }^{1}$, \\ Fabiana Maria Ruíz Lopes-Mori ${ }^{2}$, Regina Mitsuka-Breganó ${ }^{3}$, Roberta Lemos Freire $^{4}$, \\ Italmar Teodorico Navarro ${ }^{4}$, Francisco Hiroshi Matumoto ${ }^{5}$, \\ José Gonçalves Dias Neto $^{6}$, Luiz Sergio Merlini ${ }^{1}$
}

\author{
${ }^{1}$ Universidade Paranaense (UNIPAR), Umuarama-PR, Brasil. \\ ${ }^{2}$ Departamento de Medicina Veterinária Preventiva e Saúde Pública, Centro Universitário Filadélfia (UNIFIL), \\ Londrina-PR, Brasil. \\ ${ }^{3}$ Centro de Ciências Biológicas, Universidade Estadual de Londrina (UEL), Londrina-PR, Brasil. \\ ${ }^{4}$ Programa de Pós-Graduação em Ciência Animal, Universidade Estadual de Londrina (UEL), Londrina-PR, Brasil. \\ ${ }^{5}$ Laboratório de Análises Clínicas, Universidade Paranaense (UNIPAR), Umuarama-PR, Brasil. \\ ${ }^{6}$ Secretaria de Saúde, Prefeitura de Umuarama-PR, Brasil. \\ *Autor para correspondência/Corresponding author: E-mail: belcaetano@ hotmail.com
}

\begin{abstract}
Toxoplasmosis is a zoonosis caused by the Toxoplasma gondii protozoa. The congenital form happens when the parasite reaches the fetus through the placenta and causes damages of different intensities, which can be consequence of the strain virulence, of the immune response capability of the pregnant woman or even of the pregnancy stage, and can result in fetal death or severe clinical symptomatology. The aim of this paper was to determine the prevalence of antibodies to Toxoplasma gondii antibodies in pregnant woman seen at the Basic Health Units (BHU) in the city of Umuarama (PR) and check for possible toxoplasmosis associations with social-demographic characteristics, behavior and environmental variables. In this study, a total of 813 pregnant women who had their prenatal exams at the BHU in the city of Umuarama (PR) were included. Blood samples collected from these subjects were submitted to $\operatorname{IgG}$ and $\operatorname{IgM}$ anti-T. gondii antibody survey. Each pregnant woman answered an epidemiological questionnaire for the detection of variables, which were later analyzed by the EpiInfo program. The prevalence detected for $\operatorname{IgG}$ and $\operatorname{IgM}$ anti-T. gondii antibodies were 56.8\% and $1.0 \%$, respectively. The variables age group, education level, per capita income, number of pregnancies, ingestion of fresh sausage, presence of peridomiciliary cats in the backyard and the habit of ingesting farm milk showed association to the infection by $T$. gondii.
\end{abstract}

Keywords: Toxoplasma gondii; serology; zoonosis; public health, congenital toxoplasmosis.

\section{Resumo}

A toxoplasmose é uma zoonose causada pelo protozoário Toxoplasma gondii. A forma congênita ocorre quando o parasita atinge o feto via transplacentária e causa danos de diferentes intensidades, que podem ser consequência da virulência da cepa, da capacidade de resposta imune da gestante ou do período gestacional que pode resultar em morte fetal ou grave sinais clínicos. O objetivo deste trabalho foi determinar a prevalência de anticorpos anti-T. gondii em gestantes atendidas nas Unidades Básicas de Saúde (UBS) na cidade de Umuarama (PR) e verificar possíveis associações da toxoplasmose com variáveis sócio-demográfica, comportamentais e ambientais. Neste estudo, foram incluídas 813 gestantes que realizaram seu pré-natal nas UBS na cidade de Umuarama (PR). As amostras de sangue coletadas desses indivíduos foram submetidas a pesquisa de anticorpos IgG e IgM anti-T. gondii. Cada gestante respondeu um questionário epidemiológico para a detecção de variáveis, que posteriormente foram analisadas pelo programa EpiInfo. A prevalência detectada para anticorpos IgG e IgM anti-T.gondii foi de 56,8\% e 1,0\%, respectivamente. As variáveis faixa etária, nível de escolaridade, renda per capita, número de gestações, ingestão de linguiça frescal, presença de 
gatos peridomiciliares no quintal e hábito de ingerir leite de sítio apresentaram associação com a infecção por T. gondii.

Palavras-Chave: Toxoplasma gondii, sorologia, zoonoses, saúde pública, toxoplasmose congênita.

\section{Introdução}

Toxoplasmosis is a globally distributed zoonosis caused by an obligate intracellular protozoa, Toxoplasma gondii (Nicolle and Manceaux, 1909; Dubey, 1977). It is considered to have a benign course in immunocompetent people. However, in immunodepressed individuals and fetuses, it can cause severe lesions (Jeffrey et al., 2001).

The parasite life cycle is complex, involving cats as definitive hosts and humans and other warm-blooded animals as intermediary hosts (Santana et al., 2003). Transmission can happen through the ingestion of oocysts present in dirt, sand, contaminated food, or by tissue cysts through the ingestion of raw or under-cooked meat, or even congenitally (Frenkel, 2004; Santana et al., 2003).

Congenital toxoplasmosis happens when primo-infection occurs in the mother during pregnancy and the parasite reaches the fetus through the placenta, causing damages of different severities, depending on the pregnancy age, strain virulence, immune response capability of the pregnant women, or pregnancy stage (Kasper, 2002; Spalding et al., 2003; Varella et al., 2003; Montoya and Rosso, 2005; Montaño et al., 2010).

Approximately $90 \%$ of the pregnant women who are infected with $T$. gondii during pregnancy are asymptomatic, and the clinical cases of the disease are less frequent, presenting with mild signs, which make clinical diagnosis more difficult (Montoya and Rosso, 2005). Research has shown that vertical transmission is the most disturbing form of infection (Mozzato and Procianoy, 2003; Souza, 2004), since the children can present sequelae with varied severity (Souza, 2004; Rorman et al., 2006).

Toxoplasmosis prevalence and incidence vary according to demographic regions, climate characteristics, cultural factors and eating habits (Lopes et al., 2009).

The aim of this paper was to determine the prevalence of antibodies to Toxoplasma gondii in pregnant women seen at the Basic Health Units (BHU) in the city of Umuarama (PR) and check for possible toxoplasmosis associations with socialdemographic characteristics, behavior and environmental variables.

\section{Material and Methods}

The city of Umuarama is located in the Northwest region in the state of Paraná, Brazil (latitude $23^{\circ} 47^{\prime} 55$ South, longitude $53^{\circ} 18^{\prime} 48$ West) and has 100,676 inhabitants (Brasil, 2010), with miscegenation from many ethnicities, several cultural and behavioral habits, which contributes to exposure of the population to $T$. gondii.

In order to determine the size of the sample, there was an estimate that the 23 BHUs in Umuarama (PR) see 1,000 pregnant women/year, according to data provided by the Health Secretariat. An expected prevalence of $50 \%$, with a $5 \%$ error and significance level of $5 \%(\mathrm{p} \leq 0.05)$ was used, obtaining an ideal minimum number of 278 samples.

This survey included pregnant women who had their pre-natal exams in the 23 BHUs in Umuarama (PR), in any pregnancy stage, after they signed a free and informed consent form. Blood samples were collected between June, 2012 and May, 2013, totaling 813 samples.

The serum samples were submitted to IgG and $\operatorname{IgM}$ anti-T. gondii antibody survey by Microparticle Enzyme Immunoassay - MEIA $\left(\right.$ AxSYM $^{\circledR}$, Abbott Laboratories, Abbott Park, Illinois, USA) according to manufacturer instructions, performed at the Laboratory of Clinical Analyses at UNIPAR.

Pregnant women who were seropositive for $\operatorname{IgG}$ and $\operatorname{IgM}$ anti-T. gondii antibodies and were under 16-weeks pregnant also had an IgG avidity test. This serum sample was sent to the partner reference laboratory in the city of Cascavel (PR).

In order to detect the variables associated to T. gondii infection, the pregnant women were interviewed, and answered an epidemiological questionnaire containing information on socialdemographic characteristics, behavior, and environmental variables.

The information on the survey tool was stored and analyzed by the EpiInfo program (Dean et al., 1996). Chi-square or Fisher's Exact test, when appropriate, were used to check the statistic significance and Odds Ratio (OR) as an association measurement between the toxoplasma infection 
and the variables surveyed. A significance level of $5 \%$ with $\mathrm{p} \leq 0.05$ was used.

\section{Results}

The age of the pregnant women ranged between 13 and 44 years old (means $\pm \mathrm{s}=25.3 \pm$ 6.6 years).
The prevalence of detected $\operatorname{IgG}$ anti- $T$. gondii antibodies was $57.8 \%$ (470/813), and among these samples, eight were $\operatorname{IgM}$ reactive $(1.7 \%$, 8/470) (Table 1).

Table 1. Presence of IgG and IgM anti-Toxoplasma gondii antibodies in pregnant women at the Basic Health Units in the city of Umuarama, Paraná, Brazil, 2012 and 2013.

\begin{tabular}{ccc}
\hline Anti- . gondii antibodies & Prevalence (\%) & CI 95\% \\
\hline & Seropositivity & - \\
$\operatorname{IgG}(+) \operatorname{IgM}(-)$ & $462(56.8)$ & - \\
$\operatorname{IgG}(+) \operatorname{IgM}(+)$ & $08(1.0)$ & {$[54.3-61.2]$} \\
Total $=\operatorname{IgG}(+)$ & $470(57.8)$ & \\
& Susceptibility & {$[38.8-45.7]$} \\
$\operatorname{IgG}(-) \operatorname{IgM}(-)$ & $343(42.2)$ & \\
Total & $813(100.0)$ &
\end{tabular}

(+) reactive; (-) non-reactive.

Tables 2 and 3 show the factors associated with the presence of $\mathrm{IgG}$ anti- $\mathrm{T}$. gondii, which were: age group between 21 and 30 years old $(p \leq 0.0007)$ and over 30 years old $(p \leq 0.0067)$, schooling ( $>8$ years of education) $(\mathrm{p} \leq 0.0001)$, monthly family income over 351 reals $(\mathrm{p} \leq 0.006)$ and being primiparous $(\mathrm{p} \leq 0.0001)$. The behavior variables associated to the infection were: ingestion of fresh sausage $(\mathrm{p} \leq 0.016)$, presence of peridomiciliary cats $(\mathrm{p} \leq 0.018)$ and the habit of ingesting farm milk $(\mathrm{p} \leq 0.037)$.

Table 2. Social-demographic variables associated with the seropositivity of $\operatorname{IgG}$ anti-Toxoplasma gondii antibodies in pregnant women at the Basic Health Units in the city of Umuarama, Paraná, Brazil, 2012 and 2013.

\begin{tabular}{|c|c|c|c|}
\hline Variables & IgG + antibodies/ total (\%) & Odds Ratio $\left[\mathrm{CI}^{\mathrm{a}} \mathbf{9 5 \%}\right]$ & Value of $p^{b}$ \\
\hline \multicolumn{4}{|c|}{ Age group } \\
\hline$<20$ years old ${ }^{\mathrm{c}}$ & $108 / 227(47.6)$ & 1.0 reference & \\
\hline 21 - 130 years old & $265 / 430(61.6)$ & $1.77[1.26-2.48]$ & 0.0007 \\
\hline$>31$ years old & $97 / 156(62.2)$ & $1.81[1.17-2.81]$ & 0.0067 \\
\hline \multicolumn{4}{|c|}{ Schooling level } \\
\hline Until 8 years study ${ }^{\mathrm{c}}$ & $163 / 239(68.2)$ & 1.0 reference & \\
\hline Over 8 years study & $307 / 574(53.4)$ & $1.87[1.34-2.60]$ & 0.0001 \\
\hline \multicolumn{4}{|c|}{ Per capita income } \\
\hline$<350$ reals $^{\mathrm{c}}$ & $183 / 284(64.4)$ & 1.0 reference & \\
\hline$>351$ reals & $287 / 529(54.3)$ & $1.53[1.12-2.08]$ & 0.006 \\
\hline \multicolumn{4}{|c|}{ Number of pregnancies } \\
\hline Multiparous ${ }^{\mathrm{c}}$ & $299 / 459(65.1)$ & 1.0 reference & \\
\hline Primiparous & $171 / 354(48.3)$ & $2.00[1.49-2.68]$ & $<0.0001$ \\
\hline
\end{tabular}

a-CI - confidence interval.

$\mathrm{b}-$ Yates $\chi 2$ or Fisher's exact test.

c - reference category. 
Table 3. Behavioral and eating habits as variables associated with the seropositivity of IgG anti-Toxoplasma gondii antibodies in pregnant women at the Basic Health Units in the city of Umuarama, Paraná, Brazil, 2012 and 2013.

\begin{tabular}{|c|c|c|c|}
\hline Variables & IgG + antibodies/ total (\%) & Odds Ratio [CI ${ }^{\text {a }}$ 95\%] & Value of $p^{b}$ \\
\hline \multicolumn{4}{|c|}{ Ingestion of fresh sausage } \\
\hline Yes & $192 / 303(63.4)$ & $1.44[1.07-1.93]$ & 0.016 \\
\hline No & $278 / 510(54.5)$ & & \\
\hline \multicolumn{4}{|c|}{ Stray cats coming into the yard } \\
\hline Yes & $245 / 395(62.0)$ & $1.41[1.06-1.87]$ & 0.018 \\
\hline No & $223 / 416(53.6)$ & & \\
\hline \multicolumn{4}{|c|}{ Drink farm milk } \\
\hline Yes & $133 / 207(64.3)$ & $1.43[1.03-1.98]$ & 0.037 \\
\hline No & $335 / 602(55.6)$ & & \\
\hline
\end{tabular}

${ }^{\mathrm{a}} \mathrm{CI}$ - confidence interval.

b - Yates $\chi^{2}$ or Fisher's exact test.

\section{Discussion}

This is the first seroepidemiological study performed in pregnant women in Umuarama (PR), which detected the prevalence of $57.8 \%$ IgG antiT. gondii antibodies. Similar results were found in Porto Alegre (RS), São José do Rio Preto (SP) and Pelotas (RS), detecting 59.8\%, 57.3\% and 54.8\%, respectively (Varella et al., 2003; Galisteu et al., 2007; Cademartori et al., 2008).

In other cities in the state of Paraná, serological surveys have shown prevalence of $56.6 \%$ and $49.2 \%$ in Londrina (Mandai et al., 2007; Lopes et al., 2009), 55.1\% in Rolândia (Dias et al., 2011) and 59.8\% and 60.6\% in Palotina and Jesuítas, respectively (Bittencourt et al., 2012).

Higher prevalence than that found in this paper was observed in Vitória (ES) (Areal and Miranda, 2008), Porto Alegre (RS) (Spalding et al., 2005), Recife (PE) (Porto et al., 2008) and Miracema (RJ) (Ribeiro et al., 2008), with serological prevalence of $73.5 \%, 74.5 \%, 74.7 \%$, and $75.1 \%$, respectively.

The different prevalence findings among the Brazilian states can be a reflection of the large territorial extension, sociocultural differences, variations in behavior and cultural habits in each region, as well as climate differences that influence the epidemiology of this disease in each study location, enabling higher or lower infection probabilities to take place (Souza et al., 2002; Couto et al., 2003; Varella et al., 2003; Bittencourt et al., 2012). According to researchers in Mato Grosso do Sul (Figueiró-Filho et al., 2005), the broad research and decentralization of the population sample could have contributed towards the different indexes for positive serology.

In this paper, the prevalence for IgM anti- $T$. gondii antibodies was $1.0 \%$, a lower result than that found in researches conducted in Palotina (PR) (Bittencourt et al., 2012), Vitória (ES) (Areal and Miranda, 2008), Londrina (PR) (Mandai et al., 2007), Rolândia (PR) (Dias et al., 2011), Miracema (RJ) (Ribeiro et al., 2008) and Recife (PE) (Porto et al., 2008), which detected 1.1\%, 1.3\%, 1.7\%, $1.9 \%, 2.0 \%$, and $2.8 \%$, respectively. In the state of Santa Catarina (Sandrin et al., 2012), researchers have found a prevalence of $0.57 \%$. Those authors have attributed the low prevalence to the undernotification of cases or to prior exposure to the parasite, to the different analysis criteria for acute infection, and different diagnostic methods.

From the 813 pregnant women, $42.2 \%$ presented seronegativity for toxoplasmosis, being susceptible to acquire the toxoplasmic infection during pregnancy. Similar results were found in Palotina (40.2\%) and Jesuítas (39.4\%) (PR) (Bittencourt et al., 2012). The authors suggest that preventive measures associated to professional health training and speed in reaching the right diagnosis and starting treatment are important forms of controlling prenatal toxoplasmosis.

In Umuarama, regarding the age group between 21 and 30 years old, and above 31 years old, the prevalence of specific IgG antibodies increased and showed that pregnant women over 31 years old showed the highest rate of infection by $T$. gondii $(\mathrm{OR}=1.81)$. This result is similar when compared to the results found in Rolândia (PR) and Londrina (PR), with pregnant women between 36 and 45 years old, and between 31 and 48 years old, respectively (Lopes et al., 2009; Dias et al., 2011). In two maternity wards in Cuiabá (MT), an association between age and seropositivity was found (Leão et al., 2004).

The results of this survey showed that for pregnant women, a per capita income above R\$ 
351.00 and schooling level higher than eight years were statistically significant, this result being contrary to the studies performed in Londrina (PR), where subjects with low per capita income $(<150.00)$ and low schooling level $(<8$ years $)$ showed greater risk of infection by $T$. gondii (Lopes et al., 2009). In the cities of Goiânia (GO) (Avelino et al., 2004) and Porto Alegre (RS) (Varela et al., 2003), results that do not corroborate the results found in this paper were found, reporting that among all variables studied, the schooling level below nine years $(\mathrm{OR}=2.2)$ presented a higher risk for pregnant woman to acquire toxoplasmosis.

In the present study, multiparous pregnancy showed to be a protection factor against $T$. gondii, while primiparous pregnancies had twice as high a chance of acquiring toxoplasmosis $(\mathrm{p}=<0.0001)$. This result is contrary to the ones found in Palotina (PR), where multiparous pregnant women presented 1.9 times greater chance of acquiring the infection (Bittencourt et al., 2012), and in Goiânia (GO), where it was demonstrated that pregnant women had a 2.2-fold higher risk factor for developing toxoplasmosis when compared to nonpregnant women (Avelino et al., 2003).

According to behavioral variables, the consumption of fresh sausage was a significant factor $(p=0.016)$, since $63.4 \%$ of the pregnant women ingesting this type of food were positive for toxoplasmosis. This result does not corroborate the studies performed in Palotina and Jesuítas (PR), where no association of this variable with the infection was detected (Bittencourt et al., 2012).

The presence of peridomiciliary cats had a significant association with the positive results for toxoplasmosis, corroborating a study carried out in Londrina (PR), which demonstrated that the presence of cats in the homes of pregnant women was associated with a greater chance of $T$. gondii infection (Lopes et al., 2009). In Goiânia (GO), they analyzed pregnant and non-pregnant women and found that the presence of a cat was a risk factor only for pregnant women (Avelino et al., 2004). The presence of a cat at home was not enough to increase the risk of acquiring the $T$. gondii infection, but it can be related to infected bird and rodent populations that feed the felines (Dubey, 2010).

In Umuarama, the association between pregnant women's seropositivity and the consumption of farm milk was significant, corroborating the work performed in Pelotas (RS)
(Cadermatori et al., 2008). However, in a study developed by Chiari and Neves (1984), the authors reported three cases of acute toxoplasmosis in Belo Horizonte in people of the same family, related to the intake of unpasteurized and unboiled goat's milk and concluded that the infection was caused probably by the penetration of the parasite through the mucosa of the mouth and pharynx.

\section{Conclusion}

The serological results and variables associated to the toxoplasmic infection in this paper reflect the importance of analyzing and knowing the local epidemiology in order to propose educational programs with primary prevention measures against the infection by $T$. gondii. The implementation of congenital toxoplasmosis monitoring programs aims to control seroconversion and detect acute infection by $T$. gondii, minimizing the damages to the fetus.

\section{Acknowledgments}

The authors would like to thank UNIPAR and CAPES for the financial support granted to this research, the Laboratory of Clinical Analyses at UNIPAR for the serological diagnoses, the Municipal Health Secretariat and all pregnant women taking part in the project for their ongoing collaboration.

\section{Conflict of Interest}

The author(s) have not declared any conflict of interest.

\section{Ethics Committee}

This paper was approved by the Ethics Committee in Research Involving Human Beings (Comitê de Ética em Pesquisa Envolvendo Seres Humanos - CEPEH) from Universidade Paranaense (UNIPAR) under protocol 22383/2012.

\section{References}

Areal, K.R.; Miranda, A.E. Soroprevalência de toxoplasmose em gestantes atendidas na rede básica de saúde de Vitória, ES. Revista Newslab, 87:122-129, 2008.

Avelino, M.M.; Campos Jr., D.; Parada, J.B.; Castro, A.M. Risk factors for Toxoplasma gondii infection in women of childbearing age. Brazilian Journal of Infectious Diseases, 8(2):164-174, 2004.

Avelino, M.M.; Campos, D.Jr.; Parada, J.C.B.; Castro, A.M. Pregnancy as a risk factor for 
acute toxoplasmosis seroconversion. European Journal of Obstetrics, Gynecology and Reproductive Biology, 108(1):19-24, 2003.

Bittencourt, L.H.F.B.; Lopes-Mori, F.M.R.; Mitsuka-Breganó, R.; Valentim-Zabott, M.; Freire, R.L.; Pinto, S.B.; Navarro, I.T. Soroepidemiologia da toxoplasmose em gestantes a partir da implantação do Programa de Vigilância da Toxoplasmose Adquirida e Congênita em municípios da região oeste do Paraná. Revista Brasileira de Ginecologia e Obstetrícia, 34(2):63-68, 2012.

BRASIL [homepage on the Internet]. Brasil. Instituto Brasileiro de Geografia e Estatística. Cidades, 2010. [updated 2013 January 10; cited 2013 January 10]. Available from:

http://www.ibge.gov.br/cidadesat/topwindow .htm?1

Cademartori, B.G.; Farias, N.A.R.; Brod, C.S. Soroprevalência e fatores de risco à infecção por Toxoplasma gondii em gestantes de Pelotas, sul do Brasil. Revista Panamericana de Infectologia (Online), 10(4):30-35, 2008.

Chiari, C.A.; Neves, D.P. Toxoplasmose humana adquirida através da ingestão de leite de cabra. Memórias do Instituto Oswaldo Cruz, 79(3):337-340, 1984.

Couto, J.C.F.; Melo, R.N.; Rodrigues, M.V.; Leite, J.M. Diagnostico pré-natal e tratamento da toxoplasmose na gestação. Federação Brasileira das Sociedades de Ginecologia e Obstetrícia, 31:85-90, 2003.

Dean, A.G.; Dean, J.A.; Coulomerier, D.; Smith, D.C.; Brendel, K.A.; Arner, T.G. Epi Info, Version 6: a word processing, data bases, and statistic program for epidemiology on microcomputers. Center for Diseases Control and Prevention, Atlanta - Georgia, U.S.A. 1996.

Dias, R.C.F.; Lopes-Mori, F.M.R.; MitsukaBreganó, R.; Dias, R.A.F.; Tokano, D.V.; Reiche, E.M.V.; Freire, R.L.; Navarro, I.T. Factors associated to infection by Toxoplasma gondii in pregnant women attended in basic health units in the city of Rolândia, Paraná, Brazil. Revista Brasileira de Medicina Tropical, 53(4):185-191, 2011.

Dubey, J.P. Toxoplasma, Hammondia, Besnoitia, Sarcocystis and other tissue cyst-forming coccidia of man and animals. In: Kreier, J. P.
Parasitic Protozoa, New York; Academic Press. 1977.

Dubey, J.P. Toxoplasmosis of animals and humans. Second Edition, Florida, USA: Boca Raton, CRC Press, 2010, 940p.

Figueiró-Filho, E.A.; Lopes, A.H.A.; Senefonte, F.R.A.; Souza-Júnior, V.G.; Botelho, C.A.; Figueiredo, M.S.; Duarte, G. Toxoplasmose aguda: estudo da frequência, taxa de transmissão vertical e relação entre os testes diagnósticos materno-fetais em gestantes em estado da Região Centro-Oeste do Brasil. Revista Brasileira de Ginecologia e Obstetrícia, 27(8):442-449, 2005.

Frenkel, J.K. Toxoplasmose. In: Veronesi, R. Tratado de infectologia. 2. ed., São Paulo: Atheneu, 2004, 1325p.

Galisteu, K.J.; Mattos, C.B.; Lelis, A.G.L.; Oliveira, M.P.; Spejorim, L.F.; Jordão, P.; Zago, A.P.; Cury, P.M.; Mattos, L.C.; Rossit, A.R.B.; Cavasini, C.E.; Machado, R.L.D. Prevalência e fatores de risco associados à toxoplasmose em grávidas e suas crianças no Noroeste Paulista, Brasil. Revista Panamericana de Infectologia, 9(4):24-29, 2007.

Jeffrey, J.L.; Lopez, A.; Wilson, M.; Schulkin, J.; Gibbs, R. Congenital toxoplasmosis: a review. Obstetrics and Gynecology, 56(5):296-300, 2001.

Kasper, L.H. Infecção por toxoplasma. In: Braunwald, E.; Fauci, A.S.; Kasper, D.L.; Hauser, S.L.; Longo, D.L.; Jameson, J.L. editors. Harrison Medicina Interna. 15. ed. Rio de Janeiro: McGraw-Hill; 2002, 1298p.

Leão, P.R.D.; Meirelles Filho, J.; Medeiros, S.F. Toxoplasmose: soroprevalência em puerperas atendidas pelo Sistema único de Saúde. Revista Brasileira de Ginecologia e Obstetrícia, 26(8):75-84, 2004.

Lopes, F.M.R.; Mitsuka-Breganó, R.; Gonçalves, D.D.; Freire, R.L.; Karigyo, C.J.T.; Wedy, G.F.; Matsuo, T.; Reiche, E.M.V.; Morimoto, H.K.; Capobiango, J.D.; Inoue, I.T.; Garcia, J.L.; Navarro, I.T. Factors associated with seropositivity for anti-Toxoplasma gondii antibodies in pregnant women of Londrina, Paraná, Brazil. Memórias do Instituto Oswaldo Cruz, 104(2):378-382, 2009.

Mandai, O.N.; Lopes, F.M.R.; Mitsuka-Breganó, R. Prevalência de anticorpos IgG e IgM antiToxoplasma gondii em gestantes atendidas nas unidades básicas de saúde do município de 
Londrina - Paraná, no período de 2003 e 2004. Revista Brasileira de Análises Clinicas, 39(4):247-249, 2007.

Montaño, P.Y.; Cruz, M.A.; Ullmann, L.S.; Langoni, H.; Biondo, A.W. Contato com gatos: um fator de risco para a toxoplasmose congênita? Clínica Veterinária, 86:78-84, 2010.

Montoya, J.G.; Rosso, F. Diagnosis and management of toxoplasmosis. Clinics in Perinatology, 32(3):705-26, 2005.

Mozzato, L.; Procianoy, R.S. Incidence of congenital toxoplasmosis in southern Brasil: a prospective study. Revista del Instituto de Medicina Tropical, 45(3):147-151, 2003.

Nicolle, C.; Manceaux, L. Sur um protozoaire nouveau du gondii. CR Academic Science, 28:763-766, 1909.

Porto, A.M.F.; Amorim, M.M.R.; Coelho, I.C.N.; Santos, L.C. Perfil sorológico para toxoplasmose em gestantes. Revista da Associação Médica Brasileira, 54(3):242248, 2008.

Ribeiro, A.C.; Mutis, M.C.S.; Fernandes, O. Association of the presence of residual antiToxoplasma gondii IgM in pregnant women and their respective family groups in Miracema, Norwest Rio de Janeiro Brazil. Memórias do Instituto Oswaldo Cruz, 103(6):591-594, 2008.

Rorman, E.; Zamir, C.S.; Rilkis, I.; Ben-David, H. Congenital toxoplasmosis - prenatal aspectos of Toxoplasma gondii infection. Reproductive Toxicology, 21(4):458-472, 2006.
Sandrin, L.N.A.; Ponzi, C.C.; Binda, G.; Nardi, A. Perfil epidemiológico de toxoplasmose em gestantes. Journal of the Brazilian Society of Internal Medicine, 10(6):486-489, 2012.

Santana, R.M.; Andrade, F.M.; Moron, A.F. Infecções TORCH e gravidez. In: Prado F.C.; Ramos J.; Ribeiro do Valle, J. Atualização terapêutica. 21. ed. São Paulo: Artes Médicas; 2003. p.1111-1112.

Souza, A.E.S.; Souza, D.C.; Gomez, J.G.; Matos, C.S. Ocorrência de anticorpos antiToxoplasma em pacientes atendidos no Laboratório Celso Matos - Santarém, PA. Revista Brasileira de Análises Clínica, 34:51-52, 2002.

Souza, M. Assistência de enfermagem em infectologia. Exemplar 1, Atheneu, São Paulo, SP. 2004, 351p.

Spalding, S.M.; Amendoeira, M.R.; Klein, C.H.; Ribeiro, L.C. Serological screening and toxoplasmosis exposure factors among pregnant women in south of Brazil. Revista da Sociedade Brasileira de Medicina Tropical, 38(2):173-177, 2005.

Spalding, S.M.; Amendoeira, M.R.R.; Ribeiro, L.C.; Silveira, C.; Garcia, A.P.; Camillo, C.L. Estudo prospectivo em gestantes e seus bebês com risco de transmissão de toxoplasmose congênita em um município do Rio Grande do Sul. Revista da Sociedade Brasileira de Medicina Tropical, 36(4):483-491, 2003.

Varella, I.S.; Wagner, M.B.; Darela, A.C.; Nunes, L.M.; Muller, R.W. Seroprevalence of toxoplasmosis in pregnant women. Jornal de Pediatria, 79(1):69-74, 2003. 